\title{
THE ASSOCIATION OF THE GOATFISH MULLOIDICHTHYS MARTINICUS WITH THE GRUNT HAEMULON CHRYSARGYREUM: AN EXAMPLE OF PROTECTIVE MIMICRY
}

\author{
João Paulo Krajewski ${ }^{1 *}$, Roberta Martini Bonaldo ${ }^{1}$, Cristina Sazima ${ }^{1,2}$ \& Ivan Sazima ${ }^{1}$
}

Biota Neotropica v4 (n2) http://www.biotaneotropica.org.br/v4n2/pt/abstract?shortcommunication+BN02704012004

\author{
Date recived: 04/14/2004 \\ Revised : 06/30/2004 \\ Accepted: 07/01/2004
}

1) Departamento de Zoologia e Museu de História Natural, CP 6109, Universidade Estadual de Campinas, 13083-970 Campinas, São Paulo, Brazil (www.unicamp.br)

*Corresponding author. Tel: + 55-19-3255 2038; fax: +55-19-3254 2177; e-mail: jpk@cursos.zzn.com

2) Departamento de Zoologia, Caixa Postal 199, Universidade Estadual Paulista, 13506-900 Rio Claro, SP, Brazil

\begin{abstract}
A presumed example of protective mimicry between the yellow goatfish, Mulloidichthys martinicus (Mullidae) and the smallmouth grunt, Haemulon chrysargyreum (Haemulidae) is described from Fernando de Noronha Archipelago, NE Brazil. The goatfish and the grunt share a similar overall shape and colour pattern. We found that these two species regularly form mixed schools around reefs. Additionally, when chased small groups of yellow goatfish join schools of smallmouth grunts and behave like them. The colour and shape resemblances between the two species enable their mixed schooling, and enhance the protection against visually oriented predators for both of them. Thus, we suggest that the protective association herein reported for the goatfish and the grunt may be considered as a "social mimicry", since neither species is venomous, poisonous or strongly armed. Furthermore, we suggest that additional instances of social mimicry may involve the yellow goatfish and other striped Haemulon species.
\end{abstract}

Key words: Protective mimicry, social mimicry, mixed schooling, Mulloidichthys martinicus, $\underline{\text { Haemulon chrysargyreum. }}$

\section{Resumo}

Descrevemos aqui um possível exemplo de mimetismo de proteção entre o saramunete Mulloidichthys martinicus (Mullidae) e a xira Haemulon chrysargyreum (Haemulidae), no Arquipélago de Fernando de Noronha, Nordeste do Brasil. O saramunete e a xira são semelhantes entre si, no padrão de coloração e no formato do corpo. Observamos que estas duas espécies formam cardumes mistos regularmente, ao redor de recifes. Quando perseguidos, pequenos grupos isolados de saramunetes se associam aos cardumes de xira e se comportam de modo semelhante às xiras. As semelhanças de formato e coloração entre as duas espécies provavelmente facilitam a formação de cardumes mistos e aumentam a proteção contra predadores visualmente orientados, para ambas as espécies. Assim, acreditamos que a associação protetora entre o saramunete e a xira pode ser considerada como um tipo de "mimetismo social”, uma vez que nenhuma destas espécies é venenosa, peçonhenta ou tem fortes estruturas mecânicas de defesa. Sugerimos, ainda, que exemplos adicionais de mimetismo social possam envolver o saramunete e outras espécies listradas de Haemulon.

Palavras-chave:Mimetismo de proteção, mimetismo social, cardumes mistos, Mulloidichthys martinicus, $\underline{\text { Haemulon }}$ chrysargyreum. 


\section{Introduction}

Grunts (Haemulidae) are mostly nocturnal benthic feeders which during the day are found in size-variable, inactive schools around reefs primarily for protection from incoming open water predaceous fishes (Randall 1967, 1996). Grunts form a regular component of shallow water reef fish communities in the tropical Western Atlantic (Randall 1967, Ehrlich \& Ehrlich 1972). The smallmouth grunt, Haemulon chrysargyreum, is a common reef species in the Western Atlantic (Humann \& DeLoach 2002) but restricted to oceanic islands in Brazil (Rocha \& Rosa 1999). It forages mostly at night and forms large inactive schools around shallow reefs during the day (Randall 1967). The yellow goatfish, Mulloidichthys martinicus (Mullidae), forages over sandy bottom both during day and night (Randall 1967, 1996; Munro 1976). The goatfish also forms inactive schools around reefs during the day, but generally with much fewer individuals than the grunt's schools (pers obs.).

Heterotypic schools of yellow goatfishes and grunts, mostly species of the genus Haemulon, are widespread in the tropical Western Atlantic (Ehrlich \& Ehrlich 1972). The fishes within these mixed schools seem to gain protection against predators by increasing the numbers of individuals that are similar in shape and colour pattern and thus have the potential to confuse visually hunting fishes (Ehrlich \& Ehrlich 1972). This mixed schooling is called social mimicry (Moynihan 1968, Randall \& McCosker 1993), synergic inviting mimicry (Vane-Wright 1976), or school oriented mimicry (Dafni \& Diamant 1984). In all cases the similarity between the fish species that compose the mixed school probably facilitates schooling and enhances the school cohesion. Although grunt-goatfish mixed schools are a common sight in the tropical Western Atlantic, there are no reports on the behaviour of these fishes during the group formation, and under which circumstances these mixed groups are formed.

At the Fernando de Noronha Archipelago, off NE Brazil, the yellow goatfish and the smallmouth grunt are regularly found in inactive mixed schools around the reefs. Herein we report on the behaviour of the schools formed by the smallmouth grunt and the yellow goatfish only, as well as mixed schools of both species. We suggest that the resemblance and the association between these two fish species is an example of protective social mimicry. Furthermore, we surmise that this form of protection may be widespread among goatfishes and other similarly-looking, schooling fish species in other regions.

\section{Materials and methods}

The study was conducted at the Fernando de Noronha Archipelago (0350' S; 32²5' W), 340km off north-eastern Brazil, in June and July 2002 and June 2003. We ob- served, video-recorded and photographed the behaviour of 10 schools of smallmouth grunt, 13 groups of yellow goatfish and 17 mixed schools of the two species, totalling 36 hours of scuba-diving at several sites. Additionally, to simulate a chasing predator, we threatened (by swimming straightforward towards the fishes) seven schools of about 10-50 yellow goatfish that were inactive and sheltered in the reef, and three groups of about 4-10 ones that were foraging on the sandy bottom in the open. We chased the groups to induce them to swim into open water and recorded the behaviour of each group. During the study the depth ranged 4-15 m and horizontal visibility ranged 10$30 \mathrm{~m}$. Size of fishes is given as total length (TL) estimates.

\section{Results}

Mulloidichthys martinicus and Haemulon chrysargyreum have a similar resemblance in overall shape and colour pattern (Figure 1). At several sites in the archipelago the yellow goatfish formed schools of about 4-50 individuals, and the grunt usually formed schools of about 40-1000 individuals. The monotypic inactive groups of yellow goatfishes were found sheltered under ledges or in crevices in the reef, or were foraging on the sandy bottom in the open. On the other hand, monotypic schools of the smallmouth grunt were always found inactive in the water column in the open. The yellow goatfishes while in the water column in the open were always mixed within the larger schools of inactive smallmouth grunts (Figure 1). Within the mixed school, the yellow goatfish hovered in a head-down, oblique posture similar to that displayed by the grunts within the school (Figure 2). The yellow goatfish and smallmouth grunts that we recorded mixed together were of similar size class (15-20 cm TL) and in only one small mixed school the yellow goatfish outnumbered (by about 10 individuals) the smallmouth grunt. Although the yellow goatfish appears to be a conspicuous fish when solitary or in small groups, its colour pattern renders it inconspicuous while schooling along with the smallmouth grunt (Figure 1). Experimentally chased groups of yellow goatfish immediately joined the schools of the smallmouth grunt when the former fish were induced to flee into open water (Figure 3).

\section{Discussion}

We regard the association of the yellow goatfish with the smallmouth grunt as an example of protective mimicry, so called social mimicry (Moynihan 1968, Randall \& McCosker 1993), synergic inviting mimicry (Vane-Wright 1976), and school oriented mimicry (Dafni \& Diamant 1984), since for all these categories a defensive function was indicated. Our assumption is based in the fact that these two species associate in mixed schools and are similar in shape and colour pattern. Additionally, when threat- 


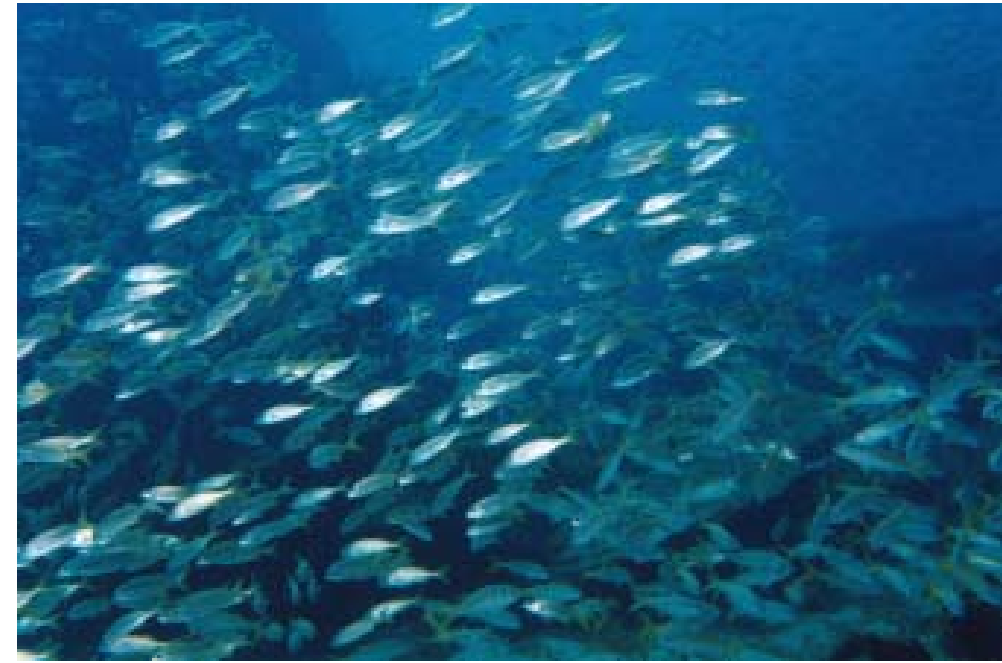

Figure 1 - The yellow goatfish (Mulloidichthys martinicus) is difficult to tell apart from the smallmouth grunt (Haemulon chrysargyreum) while in mixed schools and viewed under natural light.

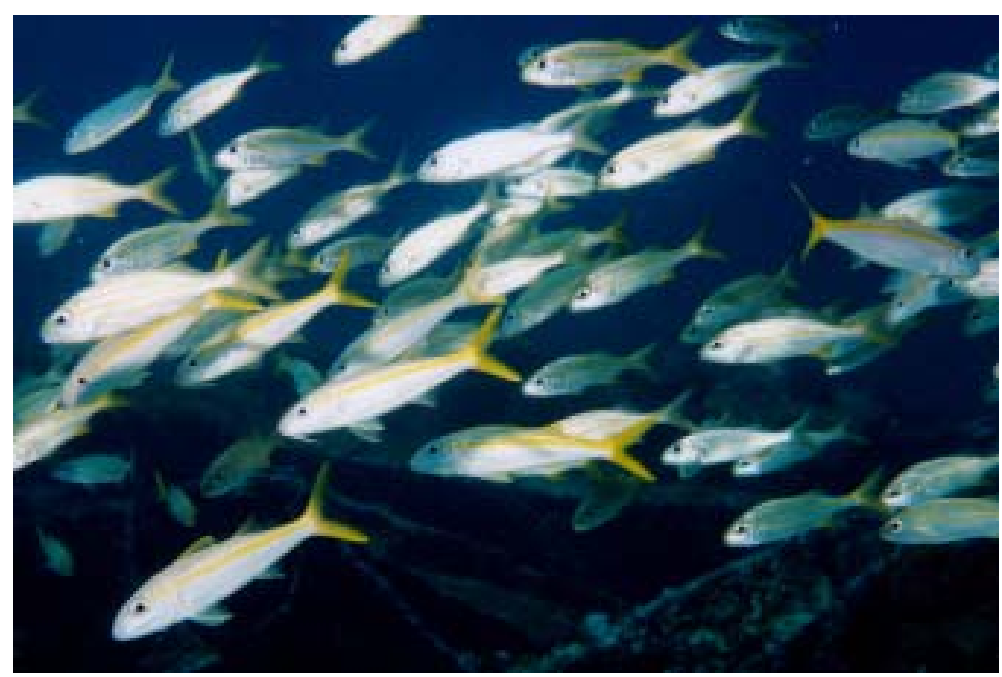

Figure 2 - The yellow goatfish adopts similar posture and behaviour while in a mixed school with the smallmouth grunt. Note overall resemblance in shape and pattern between the two species even under artificial light.

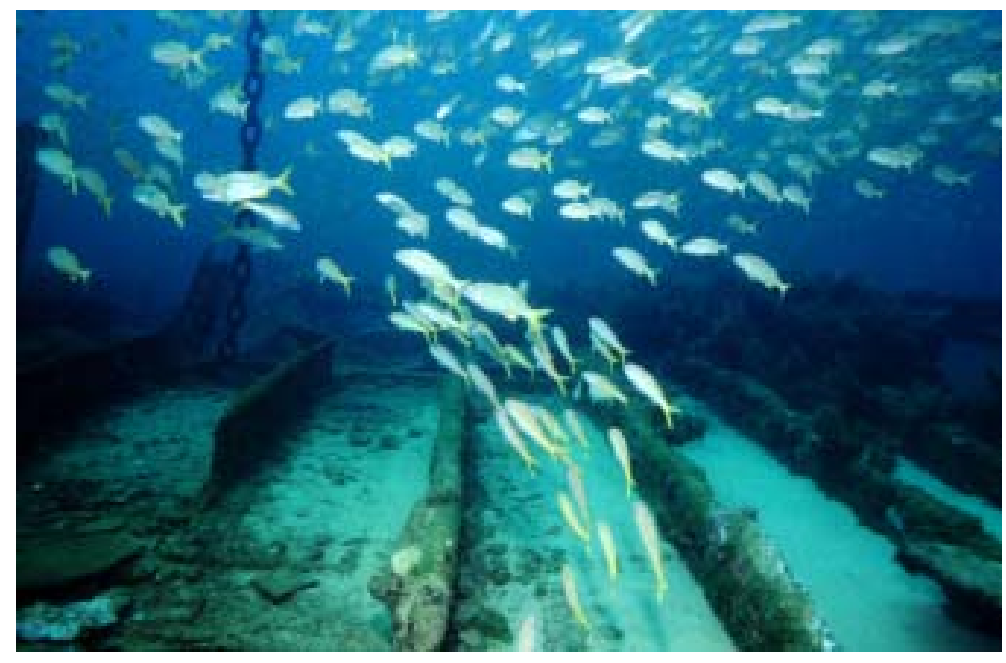

Figure 3 - A previously inactive group of yellow goatfish (lower fish) joins a smallmouth grunt school when chased by a would be predator (in this case a diver). 
ened, the yellow goatfish always joined the larger schools of smallmouth grunt and behaved like them. The case herein reported cannot be regarded as an example of Batesian or Müllerian mimicry (Vane-Wright 1976), since the two fish species are neither venomous nor poisonous, and do not appear to display any other feature which would deter or confound potential predators (Dafni \& Diamant 1984, Randall 1996, Froese \& Pauly 2004).

This mixed schooling behaviour may be considered as advantageous for both the smallmouth grunt and the yellow goatfish since their overall numbers increase while mixing, and thus confuse visually hunting predators when targeting on its prey. However, as the goatfish is generally less abundant than the smallmouth grunt (pers obs.), the association much likely is more advantageous to the yellow goatfish than to the smallmouth grunt. Moreover, the goatfish forage on sandy bottoms away from reef shelters and thus they must rely on swimming off into open water as a form of defence against potential predators (Gosline 1984). Therefore, we regard the large smallmouth grunt schools as very important and predictable refuges for the yellow goatfish while fleeing in open water. We predict that the yellow goatfish would join schools of other striped grunt species along the Brazil's coast, Haemulon squamipinna in Northeast Brazil and H. aurolineatum anywhere on the coast being likely candidates for such mixed associations.

Since the genus Haemulon is restricted to the New World (both in the Atlantic and Pacific), whereas Mulloidichthys is widespread in warm seas (Allen \& Robertson 1994), it would be of interest to check which additional genera and/or species these goatfishes associate with. For instance, the Indo-Pacific Mulloidichthys mimicus joins schools of the very similar lutjanid Lutjanus kasmira during the day (Allen et al. 2003, Froese \& Pauly 2004). The yellow-striped goatfishes M. flavolineatus and $M$. manicolensis display a colour pattern similar to that of the schooling caesionids Pterocaesio chrysozona and $P$. digramma (Froese \& Pauly 2004), also from the Indo-Pacific, and perhaps represent additional instances of social, protective mimicry.

\section{Acknowledgements}

We thank two anonymous reviewers for greatly improving our manuscript; F. C. Silva for photo and video gear; G. A. G. Pereira for flying tickets; J. M. Silva-Jr (Centro Golfinho Rotador) for logistical and other help; the Atlantis Diving Center for allowing free use of its facilities; the Ibama for permits to study reef fishes at the Fernando de Noronha National Marine Park; the CAPES, CNPq, FAPESP and PROAP-Unicamp for financial support.

\section{References}

ALLEN, G.R. \& ROBERTSON, D.R. 1994. Fishes of the tropical eastern Pacific. Univ. Hawaii Press. Honolulu.

ALLEN, G.R., STEENE, R, HUMANN, P. \& DeLOACH, N. 2003. Reef fish identification - Tropical Pacific. New World Publications. Jacksonville.

DAFNI, J. \& DIAMANT, A. 1984. School-oriented mimicry, a new type of mimicry in fishes. Mar. Ecol. Progr. Ser. 20: 45-50.

EHRLICH, P.R. \& EHRLICH, A.H. 1972. Coevolution: heterotypic schooling in Caribbean reef fishes. Am. Nat. 107: 157-160.

FROESE, R. \& PAULY, D. (Eds) 2004. FishBase. World Wide Web electronic publication. www.fishbase.org, version 04/2004.

GOSLINE, W. A. 1984. Structure, function, and ecology in the goatfishes (family Mullidae). Pacif. Sci. 38: 312-323.

HUMANN, P. \& DeLOACH, N. 2002. Reef fish identification: Florida, Caribbean, Bahamas. New World Publications. Jacksonville.

MOYNIHAN, M. 1968. Social mimicry; character convergence versus character displacement. Evolution 22 (2): 315-331.

MUNRO, J.L. 1976. Aspects of the biology and ecology of Caribbean reef fishes: Mullidae (goatfishes). J. Fish Biol. 9: 79-97.

RANDALL, J.E. 1967. Food habits of reef fishes of the West Indies. Stud. Trop. Oceanogr.5: 665-847.

RANDALL, J.E. 1996. Caribbean reef fishes. $3^{\text {rd }}$. ed. T.F.H. Publications. Neptune City.

RANDALL, J.E. \& McCOSKER, J.E. 1993. Social mimicry in fishes. Revue Fr. Aquariol. 20:5-8.

ROCHA, L.A. \& ROSA, I.L. 1999. A new species of Haemulon (Teleostei: Haemulidae) from the Northeastern Brazilian coast. Copeia 1999(2): 447-452.

VANE-WRIGHT, R.I. 1976. A unified classification of mimetic resemblances. Linn. Soc. Lond 8 (1): 25-56.

Title: The association of the goatfish Mulloidichthys martinicus with the grunt Haemulon chrysargyreum: an example of protective mimicry

Authors: João Paulo Krajewski, Roberta Martini Bonaldo, Cristina Sazima \& Ivan Sazima

Biota Neotropica, Vol. 4( number 2): 2004 http://www.biotaneotropica.org.br/v3n1/pt/ abstract?article+BN00303012003

Date recived: 04/14/2004 - Revised : 06/30/2004 Accepted: 07/01/2004 